\title{
DIFFICULT NEIGHBORHOODS. REPRESENTATIVE SPACES AND NEGLECTED AREAS ON THE EXAMPLE OF TOMSK
}

\author{
Joanna Panciuchin \\ Uniwersytet Wrocławski, Poland \\ panciuchin@gmail.com
}

The article concerns bottom-up creative acts oriented toward the transformation of urban space. Objects that are the result of these activities represent something that can be called alternative urban aesthetics. Basing on the results of research conducted in Siberian Tomsk, as well as photographic material collected as part of research projects such as "Invisible City", the author tries to prove that the described phenomena in the urban iconosphere have a global character. The "invisible" activities of the city's inhabitants are spontaneous forms of creative activity. These are traces of being and inhabitation left by the very people who create urban space. The residents who are the active actors, not only modifying but also creating the surrounding space. Importantly, these practices have material implications, thus affecting the appearance, organization and dominant aesthetics of cities. The "invisibles" are often assigned to the spheres of kitsch and bad taste because they quite strongly break the established and valid canons. However, paradoxically, alternative aesthetics have their own internal canon, too. As its basic principles, we can identify re / upcycling, independent construction of objects, avoiding abstractness, and referring to animal and plant shapes not necessarily known from the surroundings, as well as an unusual community of forms that cannot be denied in its global character. From 2015 the author has participated in a research project called "Visual organizations of urban space: behaviors, interpretations, historical and cultural perspectives. Comparative analysis of the iconosphere and its relations to the ways of life of Russian Tomsk and Polish Wroclaw inhabitants". Tomsk turned out to be extremely abundant in "invisibility". In almost every courtyard, whether adjacent to modernist blocks of the Soviet period (the so-called big slab, that is large panel system-building), or to unique, wooden single- and multi-family houses, the author has found examples of spontaneous creative activity by residents. Tomsk's residents transform unnecessary objects or materials into installations whose primary function is to "tame" and "embellish" the nearest - often dehumanized - space, as well as work to solve everyday problems and shortages. Bricoleur-like minds and hands are then transforming rubbish and fragmented objects into emancipating entities. Invisible objects introduce familiarity and mark the presence of the creators / residents who, by adopting an active attitude, thus decide about the image of those city fragments. These creative acts "give" their power back to them and the objects produced in this way are characterized by a very special position in the entire universe of objects.

Keywords: urban aesthetics, city, globality, self-agency, "invisible" city, representative, neglected, urban space, urban studies. 


\title{
СЛОЖНЫЕ ОКРЕСТНОСТИ. РЕПРЕЗЕНТАТИВНЫЕ ПРОСТРАНСТВА И ЗАБРОШЕННЫЕ РАЙОНЫ (НА ПРИМЕРЕ ТОМСКА)
}

\author{
Иоанна Панчухин \\ Вроциавский университет, Польша \\ panciuchin@gmail.com
}

В статье рассматриваются преобразовательные творческие акты, направленные на трансформацию городского пространства. Объекты, являющиеся результатом этих действий, представляют собой нечто, что можно назвать альтернативной городской эстетикой. Основываясь на результатах исследований, проведённых в сибирском городе Томске, а также на фотографических материалах, собранных в рамках исследовательских проектов, таких как «Невидимый город», автор пытается доказать, что описанные явления в городской иконосфере имеют глобальный характер. «Невидимая» деятельность жителей города - это спонтанные формы творческой деятельности. Это следы бытия и проживания, оставденные теми людьми, которые создают городское пространство. Жители, которые явияются активными деятелями, не только изменяют, но и создают окружающее пространство. Важно отметить, что эта практика имеет существенные последствия, что вдияет на внешний вид, организацию и доминирующую эстетику городов. «Невидимое» часто усваивается сферам китча и дурного вкуса, потому что они довольно сильно нарушают установленные и привычные каноны. Однако, как ни парадоксально, альтернативная эстетика также имеет собственный внутренний канон. В качестве основных её принципов мы можем идентифицировать возвращение / обращение, независимое построение объектов, отказ от абстрактности, ссылки на формы животных и растений, которые необязательно известны из окружающей среды, а также необычное сочетание форм, глобальный характер которых невозможно отрицать. С 2015 года автор участвовал в исследовательском проекте под названием «Визуадьная организация городского пространства: сохранение, трансляция, историческая и культурная перспектива. Сравнительный анализ иконосферы и её соотношения с образом жизни населения российского Томска и польского Вроцлава». Томск оказался чрезвычайно богатым в своей «невидимости». Почти во всех дворах, расположенных рядом с модернистскими кварталами советского периода (так называемая система крупнопанельной застройки) или уникальными деревянными одно- и многоквартирными домами, автор нашё примеры спонтанной творческой активности местных жителей. Жители Томска превращают ненужные объекты или материалы в объекты, основная функция которых заключается в «приручении» и «приукрашивании» ближайшего, зачастую дегуманизированного, пространства, а также в работе по решению повседневных проблем и недостатков. Умы и руки, приверженные бриколажу, превращают мусор и фрагментированные объекты 
в эмансипирующие сущности. Невидимые объекты отмечают присутствие создателей / жителей, которые, заняв активную позицию, принимают решения об имидже этих фрагментов города. Такие творческие акты «дают» им свою власть, и объекты, созданные таким способом, характеризуются исключительным положением во всей вселенной объектов.

Кдючевые слова: городская эстетика, город, глобальность, самодеятельность, «невидимый» город, репрезентативное, пренебрегаемое, городское пространство, городские исследования.

DOI 10.23951/2312-7899-2018-3-76-87

The aesthetic dimension of the space of modern cities depends on the vision and decision of many agents / actors - representatives of municipalities, developers, investors, architects, urban planners, monument conservators, advertisers, and finally also residents. Importantly, of greatest interest and concern are those fragments of cities which fulfil representative functions, building "official" and "valid" images intended for dissemination. These images are then used in the processes of shaping images of the metropolis. They are concentrated on areas which are "centrally located, with structures, buildings, elements of small architecture and monuments exposed in various ways, important due to their historical value, aesthetic and artistic values, meaning for the identity of the place, etc. They are presented as the most characteristic, focusing the life of the city, determining its rhythm and pulse. They are designed to be shown, constituting the main attractions that fuel the development of the tourism industry" [Fereński 2016, 71]. Such spaces are characterized by a kind of smoothing. They are legally protected, as in cultural parks, so that only a limited number of actors would affect their appearance and shape. Thus, they are subject to continuous supervision and official inspection.

In recent years, however, we can observe a number of phenomena that can be associated with the desire of residents to exercise an influence over shaping the urban space - including its aesthetics. Tools such as the civic budget are becoming increasingly popular ${ }^{1}$. Various NGOs operate actively and the so-called urban movements are growing. Bottomup initiatives aiming to improve living conditions in the city are being launched, and the authorities are forced to conduct public consultations regarding proposed changes.

\footnotetext{
${ }^{1}$ Or "participatory budgeting", the global career of which started in South-Brasilian Porto Alegre
} in 1989 . 
I would like to devote these considerations to areas which, although in contrast to the representative spaces (e. g. Sagrada Familia, Torre Agbar and Parque Guell in Barcelona, Stefansdom, Hofburg gardens and Prater / Riesenrad in Vienna or Красная площадь in Moscow) are still less frequently studied as urban space, have nevertheless already attracted a few thorough studies, especially in Polish academic literature. It concerns specific type of grassroots initiatives, undertaken by urban residents in order to beautify their immediate environment. These are usually individual acts characterized by spontaneity, consisting in interference in the nearest space. Such realizations can be found, among other places, on the balconies, in the courtyards, and in backyard gardens, that is in unexposed places not included within the "official" images of the city. The causal agent of their emergence is the will of space users, not the visions of the local magistrates (which does not mean that they are not intercepted by the authorities and/or animated by official competitions). This sphere of so-called "urban aesthetics", after Marek Krajewski, can be called "invisible" [Krajewski 2012, 9]. The term was coined as a part of the "Invisible City" project, directed by Marek Krajewski from the University of Adam Mickiewicz in Poznan. The title "invisibility" results from the fact that research carried out as part of the whole project "concerned elements of a socially / culturally produced urban reality, which, although visible in their physical dimension, go unnoticed by residents/users of communication routes and objects in their everyday routines... It's a world next to us, but a world thoroughly overlooked" [Fereński 2016, 73]. The "invisible" activities of the inhabitants are spontaneous forms of creative activity. These are traces of being and inhabitation left by the very people who create urban space. "Demonstrating various aesthetics and imaginations about the modern city, manifestations of life and alternative actions against the urban standards and global aesthetics dominating in metropolises, has become one of the basic goals of the project discussed here" [ibid.]. The idea of this research stemmed from the statement that it is - often overlooked in the local authorities' visions - the residents who are the active actors, not only modifying but also creating the surrounding space. Importantly, the practices analysed have material implications, thus affecting the appearance, organization and dominant aesthetics of cities. In this way, the researchers paid attention to what is generally considered to be irrelevant and trivial, thus completely overlooked hence "invisible" [Krajewski 2012, 9-11]. "The project was therefore looking for the unnoticeable world next to us, for the elements of social life or cultural phenomena, for the types of activity / agency that have remained on the margins of the research so far" [Fereński 2016, 74]. 


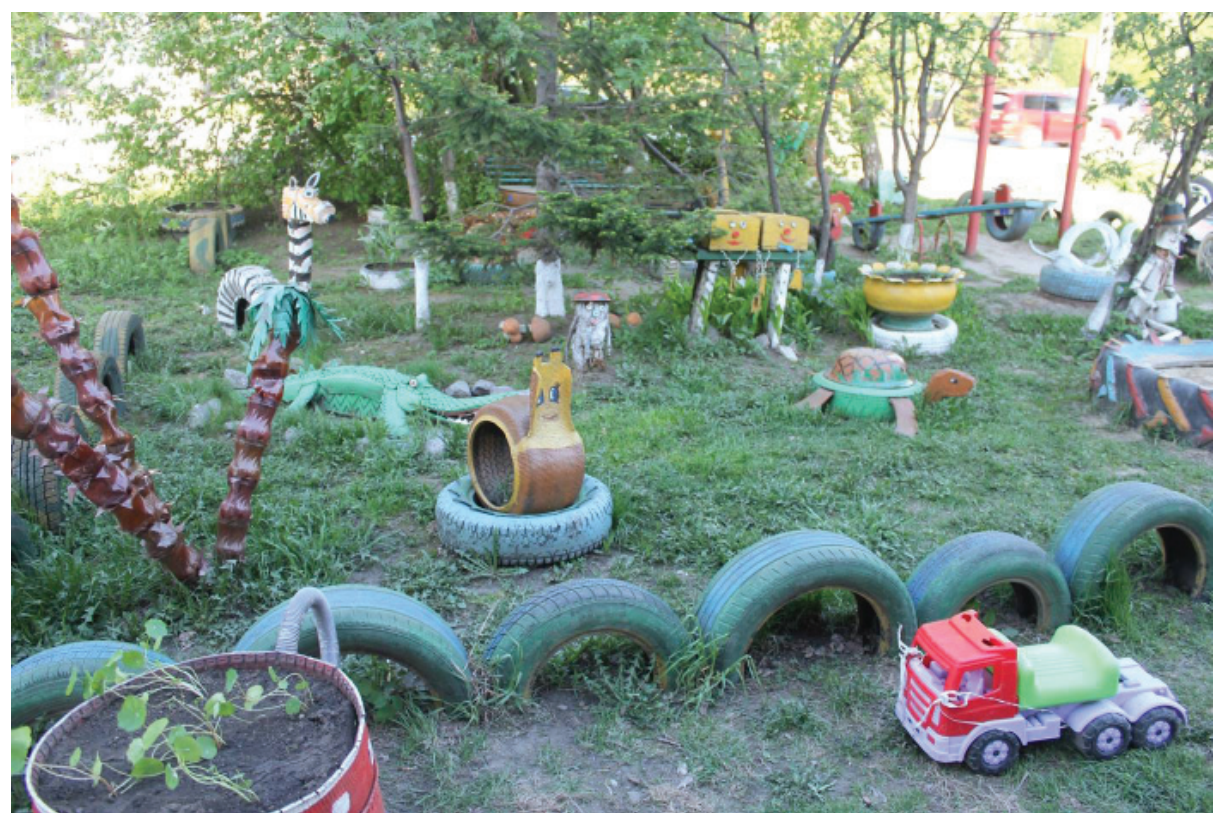

From 2015 I have participated in a research project called "Visual organizations of urban space: behaviors, interpretations, historical and cultural perspectives. Comparative analysis of the iconosphere and its relations to the ways of life of Russian Tomsk and Polish Wroclaw inhabitants", managed by one of the members of the "Invisible City" team, Piotr J. Fereński. Tomsk turned out to be extremely abundant in "invisibility". In almost every courtyard, whether adjacent to modernist blocks of the Soviet period (the so-called big slab, that is large panel system-building), or to unique, wooden single- and multi-family houses, we have found examples of spontaneous creative activity by residents. A characteristic feature of this Siberian city is its façade ${ }^{2}$ and a very strong division into representative spaces and those whose image should be less seen. The former are distinguished by the attention to the aesthetics of buildings, imposed from above (especially those located in the central part of the city, which reflect the sphere of power, the might of the country, etc.), squares, streets or recreational spaces. We won't find much "invisibility" there (with the exception of graffiti). The latter, in turn, are everyday spaces, where the economic and social problems of the inhabitants can be seen. Only selected examples of wooden

\footnotetext{
${ }^{2}$ I am referring to the fact that city administration cares only about the façades of buildings located on the most important communication routes, which represent prestigious spaces and thus are the most "visible".
} 
architecture have undergone renovation, often associated with the activities of institutions or private companies located there. The rest, abounding in unusually beautiful ornamentation, are left alone. Their inhabitants do not have the financial resources that would allow for thorough, thoughtful renovation, which is why most of the wooden houses are in poor technical condition. People living there try to adapt the buildings and their immediate surroundings to their own needs using their own resources. This results in various transformations, significantly modifying the current appearance of the buildings. A similar situation takes place in the case of panel system-built blocks of flats, whose original form has significantly degraded over several decades. As I mentioned above, the "invisibility" present in the backyard areas was an interesting issue for us. In the Tomsk home gardens "there are giraffes hiding", as well as zebras, exotic palms, small pigs, black and white swans, ladybirds, small chickens, tulips, Spanish bluebells, toadstools and suns. Of course, we are talking about representations here all of them are made of the materials close to hand: old tyres, plastic bottles, used shoes, unused pots, bowls, containers, protective helmets, variously painted stones, wooden sticks and branches. It's a textbook case of upcycling. Residents transform unnecessary objects or materials into installations whose primary function is to "tame" and "embellish" the nearest - often dehumanized - space, as well as work to solve everyday problems and shortages. Bricoleur-like minds and hands are then transforming rubbish and fragmented objects into emancipating entities. Areas forgotten by the city administration are grey, neglected and unpleasant. Invisible objects introduce familiarity to them and mark the presence of the creators / residents who, by adopting an active attitude, thus decide about the image of those city fragments. These creative acts "give" their power back to them and the objects produced in this way are characterized by a very special position in the entire universe of objects. "They belong to a fairly spacious area of the borderland, drifting between the worlds of things. This state makes it much more reasonable to talk about the aesthetics of an invisible city - firstly, from the point of view of its creators and the process of creation. Secondly, not in the context of appearance, but in terms of function and meaning, and finally thirdly - in relation to the generally accepted social order" [Kietlińska 2012, 147-148]. At first sight, these palm trees and toadstools send us back to pure kitsch. Through their fairy-tale, naive forms, pastel colors or general motley appearance, they are there to embellish and decorate the space. This, however, is only the first, very superficial layer, because in fact they hide many more levels - of symbols, values, etc. In addition, 
there is a distinct emancipatory potential there. That is to say, they are obviously related to class within society. In the suburbs of Tomsk, currently including areas where the dachas with small crops of vegetables and fruits were formerly located (today few of those remain), the magnificent villas of the wealthiest Tomsk citizens have sprung up. The arrangement of their lawns and backyards is totally different. The role of the decoration is fulfilled by ready-made items, purchased in garden stores, and the activity of the owners is limited to the selection of products, purchasing and placing them in a private space. The latter is protected against glances from the outside by high fences decorated with animal motifs (having a symbolic character) and dense shrubbery. It is completely different in the case of less prosperous settlements located in the more compact housing areas - within the city itself. The materials, from which their inhabitants create "invisible" objects clearly indicate economic shortages. People must put in a lot more imagination and effort to arrange their backyards.

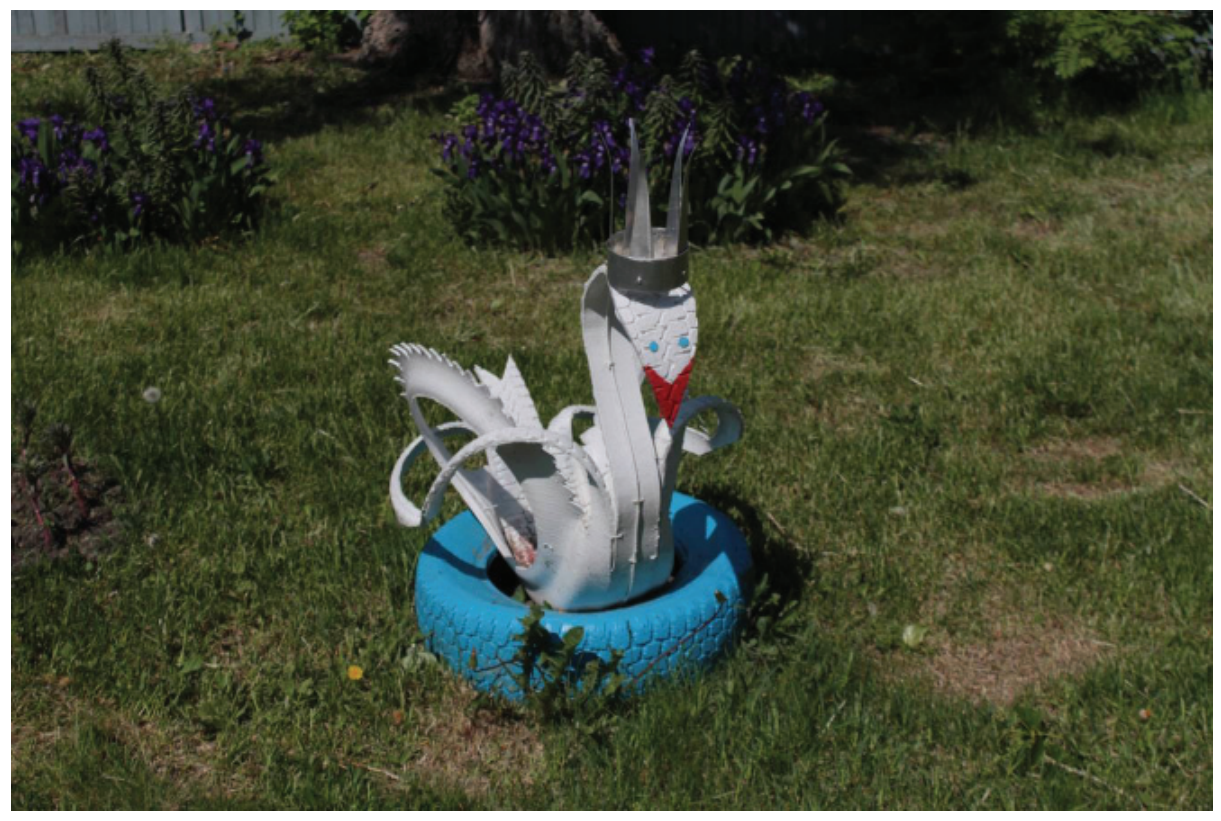

Interestingly, the Tomsk local authorities noticed this unusual activity of the citizens and made some kind of a capture. For twenty two years a competition "Tomsk's backyard" has been organized on a yearly basis. All residents of Tomsk, who in different ways take care of the spaces surrounding their houses, blocks of flats, businesses, schools, 
kindergartens, etc., may approach it. In the regulations of this year's competition, it can be read that contest is run to develop civic initiatives among urban population, encourage to create and maintain in a good condition places of recreation, as well as to create a sense of local patriotism. In addition, the competition is described as an excellent form of cooperation with the Tomsk's citizens, which will lead to a comprehensive improvement of the quality of backyards, estates and will help to create a positive opinion on the betterment of the city's functioning among residents. The contest is also intended to create a desire to take further civic initiatives for the development of Tomsk. This year, the objects are selected in categories such as a model yard, the best joint initiative of residents and property managers, the best balcony or loggia, the most beautiful flowerbed, the most beautiful arrangement of a detached house, a friendly courtyard, the best green building initiative, the best playground at school, the best kindergarten yard, the best maintained territory of the healthcare institution, the most comfortable office space or the most comfortable territory of the educational institution. The categories cited here clearly indicate that «Tomsk's backyard» is currently not only a competition for residential buildings and their surroundings, but also for public (schools, health care institutions) or private institutions (office buildings, company headquarters). The rivalry has two stages - the best projects in individual districts are selected first and then the winners of the main prizes are singled out. The jury, when issuing the verdict, is guided (depending on the category) by criteria such as: marking the participation of residents in the implementation of beautification by placing photographs or information materials in a visible place; unified implementation style; presence of greenery; maintaining cleanliness, good technical condition and functionality of the property; neat appearance of the fence and facade of the building; conducting joint events in the yard (official holidays, birthdays, sports events); originality of the project; availability of rest places; neat spaces dedicated to children [Administration 2018]. Yearly special catalogues presenting realizations are published, and for the best creators there are cash prizes - from one thousand to three thousand rubles. During the documentation of one of the greenhouses, we had the opportunity to talk to the author of the courtyard arrangement awarded by the jury. She proudly presented diplomas and newspaper clippings describing her work. Residents are adamant that although the competition is a nice initiative of the municipality, the financial incentives offered within it are not the reason for their commitment. In the local newspaper "Public Self-Government" we can read that the contest discussed 
here encourages residents who love Tomsk to take the initiative, to awaken their own creativity and use it to improve the city. In addition, it also should teach citizens the responsibility not only for private space inside homes or apartments, but also for external spaces [Antonova 2018, 8]. In turn, in the introduction to the catalog summarizing the 2017 contest, the mayor of Tomsk, Ivan Klein, emphasizes that the competition transformed the inhabitants into extremely energetic, active citizens, distinguished by love for beauty and harmony and ready to work for the city in order to make it more beautiful, cleaner and more comfortable [Klein $2017,3]$. The key category here is the transformation of "ordinary residents" into "active citizens". "Tomsk's backyard" is organized not only to encourage inhabitants to work to improve the aesthetics and functionality of common spaces, but above all to create a sense of agency among them. The local municipal council made the competition a strategy allowing to equip residents with some kind of independence and willingness to take initiatives for the benefit of the community, which can be used in the implementation of other (bottom-up) projects. What is also interesting, places marginalized on a daily basis, which do not fit into the official, used for dissemination of Tomsk's images, i. e. backyards, courtyards located next to neglected wooden houses or Soviet blocks, during the competition become (for a moment) representative areas. They are a reflection of the agility and independence of residents, which local authorities want to boast about. Of course, winning the competition does not mean that these places will be forever included in the "binding" image of the city - they are what used to be shown to tourists.

Also in Wrocław, there is a competition for residents called "Blooming Oławskie!". It does not have as many years of tradition as in Tomsk this year its first edition is taking place. It was directed to the residents of Przedmieście Oławskie, one of the most neglected Wrocław housing estates, which before the Second World War was considered as a very representative part of the city. This area has now received funding for the revitalization of architectural and social tissue. The mentioned competition is one of the elements of the revitalization strategy. The inhabitants of Oławskie from May 22 to July 31 were allowed to report their green balconies to it. Of course, this is not as extensive a form of rivalry as in Tomsk, because it only includes balconies and loggias in the apartments of private persons, but the purpose of the competition can be considered similar - creating a sense of agency among the local community.

Returning to the issue of invisibility - "invisible objects do not fit in uniform, globalized aesthetics. They constitute a breach in it, a smaller or larger crack" says Kietlińska [Kietlińska 2012,150] yet at the same 
time, their authors create a specific aesthetic framework. In many Tomsk yards, you can see similar installations, not only because of the materials used but also due to the shapes and colours. They reflect not only ideas on the world of beauty but also trends within it. The analogies mentioned are not visible just in a single city space - be it Tomsk, Poznań or Wrocław. My great-grandmother Henryka in her Wolin ${ }^{3}$ backyard had been placing and still places "invisible" objects. Most often they are shaped like toadstools or boletuses. They are made of a wooden stump and an inverted metal bowl, painted in appropriate colours. Of course, these forms are not as sophisticated and extensive as the Tomsk ones, but the tendency is very similar and is not limited to Wolin. The photographs collected by people involved in the "Invisible City" project clearly indicate that the phenomenon described is very popular in the largest Polish agglomerations. The case from Wolin illustrates that it also remains strongly present in small urban centres. However, given the examples from Siberia, can it be said to have a global character?

"Tyre-Swan-O-Rama" is a blog that was created as an expression of a fascination with used tyres turning into white or black swans. You can find there not only the documentation of these objects in various color options, but also the exact instructions for constructing your own swan. The author of the blog centrally placed the following sentence: "Documenting the tyre swans of Australia and the world" [Parry 2006], clearly indicating that such objects are not specific to Australian continent only, but are a global phenomenon. The collection of the Sydney Museum of Applied Art \& Sciences contains one specimen of a white swan made of tyres in the period between the sixties and the seventies of the twentieth century. The object was created by the owners of one of the houses in St Marys (outer western suburb of Sydney). The raw material necessary for its construction came from Czechoslovakia, and more precisely from the Barum Continental production line, one of the largest Czech manufacturers of passenger car and truck tires [Museum 2017]. Also on popular Australian online portals we can find archival advertisements about the sale of swans already ready. The examples cited here indicate that the phenomenon of creating these specific sculptures using tyres has a long tradition and is still in the aesthetic preferences of some Australians. In turn, a quick analysis of the Pinterest website seems to confirm this statement. This database of visual materials sent by users abounds in representations not only of upcycled rubber swans, but also the birds of paradise, crabs, butterflies, cockerels, various fish, and even characters from one of the most popular movies of recent years - the Minions

${ }^{3}$ Wolin is a city of ca. five thousand inhabitants in NW Poland. 
from "Despicable Me". Entries are made by individuals using languages such as English, Spanish, Russian or Chinese. Importantly, in the platform's collection, we can also find images mirroring those seen in the backyards of Tomsk. Obviously, the idea of forming a tire and a stump into the imaginary shape of a zebra or a giraffe precedes "Pinterest" and all other social media portals (which does not mean that they will not significantly contribute to the popularization of the phenomenon). We should probably ask how is it possible that people all over the world saw a swan or a palm in the tyre? For example, on the tropical Panama Bocas del Toro archipelago one can find tyres functioning as the flower pots, whose color schemes resemble ladybirds. The thing is, this beetle normally does not occur in Central America, so it is not about reproducing a form known to the artist from his closest surroundings - just as in the case of palms or exotic animals in Tomsk. It would be extremely interesting to try to trace possible ways and paths of inspiration flow, resulting in recycled "invisible" objects. Perhaps it would even be useful to turn back to some of the ideas born within the diffusionist framework?

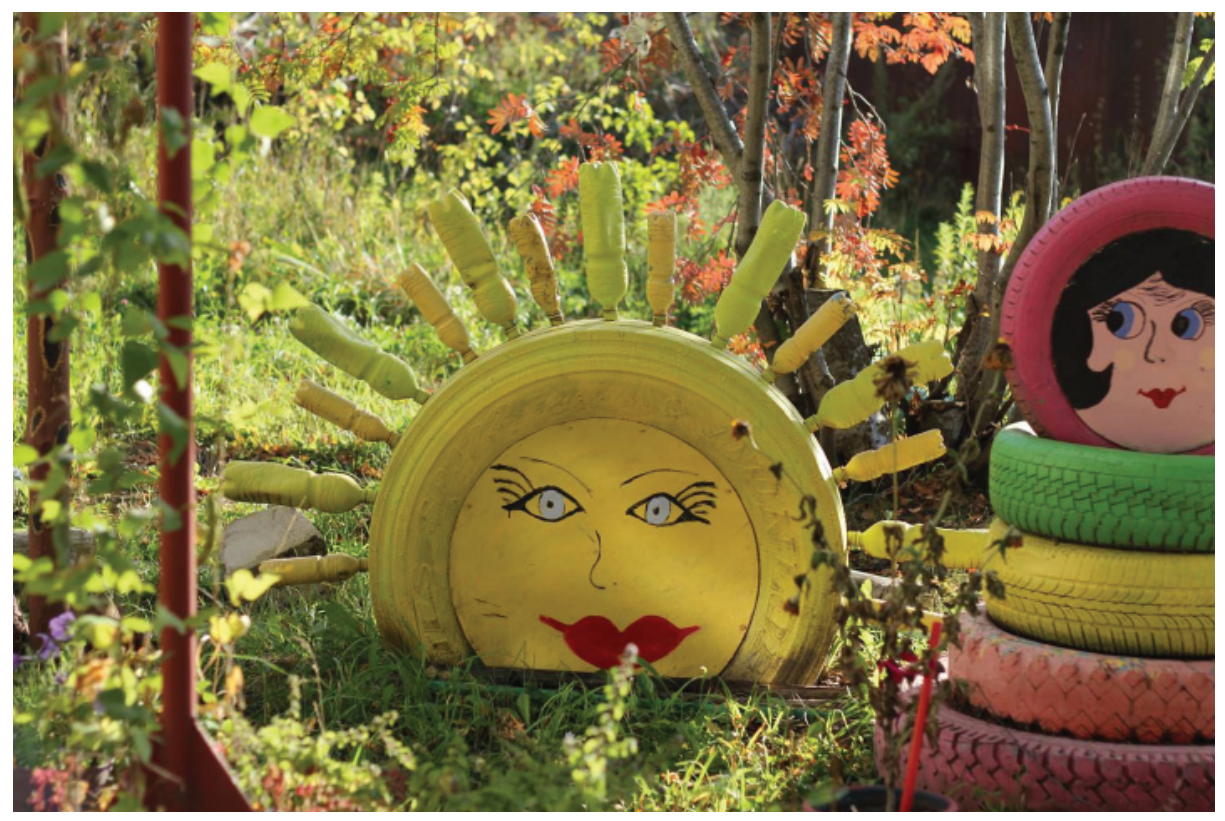

The objects described in this article seem to represent certain aesthetics of the space of cities and towns which is an alternative to the leading patterns. The "invisibles" are often assigned to the spheres of kitsch and bad taste because they quite strongly break the established and valid canons. 
However, paradoxically, alternative aesthetics have their own internal canon, too. As its basic principles, we can identify re / upcycling, independent construction of objects, avoiding abstractness, and referring to animal and plant shapes not necessarily known from the surroundings, as well as an unusual community of forms that cannot be denied in its global character. In the case of installations taking part in the competition organized by the Tomsk authorities, we can say about the temporary "triumph of invisibility". The canon of these alternative aesthetics has been extremely well integrated into the competition projects - most of them are created on the basis of recycling and bricolage. This state of affairs certainly did not arise from the municipality's initiative. The inhabitants of Tomsk created "invisible" objects before the "Tomsk's backyard". The flow of inspiration is possible not only thanks to everyday observation of the nearest urban space, but also thanks to published catalogs every year, contributed to the unusual development of these "invisible" aesthetics, and thus made them in a sense obligatory - at least for the time of the competition.

All photos: () Agnieszka Smutek

\section{REFERENCES}

Administration 2018 - Administration of the city of Tomsk. About urban competition for improvement "Tomsk's backyard". 2018. URL: http:// www.admin.tomsk.ru/pgs/8x6. In Russian.

Antonova 2018 - Antonova V. Blossom, beloved backyard! Public SelfGovernment. 2018. 4 (159). P. 8. In Russian.

Fereński 2016 - Fereński P. J. Nie-widzialne. Konteksty. Polska sztuka ludowa. 2016. 1 (312). P. 71-76.

Kietlińska 2012 - Kietlińska B. Niewidzialnomiejskie estetyki. Niewidzialne miasto. Warszawa, 2012. P. 147-156.

Klein 2017 - Klein I. Introduction. Tomsk's backyard 2017. Tomsk, 2017. P. 3. In Russian.

Krajewski 2012 - Krajewski M. Niewidzialne miasto - uspołeczniająca moc fotografii. Niewidzialne miasto. Warszawa, 2012. P. 9-24.

Museum 2017 - Museum of Applied Art \& Sciences Tyre swan. 2017. URL: https://collection.maas.museum/object/112070.

Parry 2006 - Parry C. Tyre-Swan-O-Rama. Documenting the tyre swans of Australia and the world. 2006-2013. URL: http://tyreswans.blogspot.com. 